\title{
Surface-analytical Studies on Environmental and Geochemical Surface Processes
}

\author{
Haruhiko Seyama*t and Mitsuyuki Soma** \\ *Environmental Chemistry Division, National Institute for Environmental Studies, 16-2 Onogawa, \\ Tsukuba, Ibaraki 305-8506, Japan \\ **Institute for Environmental Sciences, University of Shizuoka, 52-1 Yada, Shizuoka 422-8526, Japan
}

\begin{abstract}
The surface chemical compositions of solid samples from environmental and geological sources can differ from the bulk or average compositions, because of changes caused by adsorption, dissolution, oxidation, etc. Accordingly, analytical information on surface layers is important for a better understanding of the environmental chemistry involving solid surfaces. The rapid development of surface-analytical techniques has enabled us to probe the surface chemistry of environmental and geological solid samples of complex composition. This article demonstrates some examples of important items of information that can be obtained by applying surface-analytical techniques, such as X-ray photoelectron spectroscopy and secondary ion mass spectrometry, to environmental and geological samples. The surface analysis of fly ashes, soils, sediments and weathered silicate minerals is reviewed.
\end{abstract}

(Received November 19, 2002; Accepted January 27, 2003)

\begin{tabular}{|c|c|c|}
\hline 1 Introduction & $3 \cdot 2$ Fly ash & \\
\hline & $3 \cdot 3$ Sediment and soil & \\
\hline and Geological Samples 487 & 4 Chemical Weathering of Silicate Minerals & 492 \\
\hline $2 \cdot 1$ Electron spectroscopy & $4 \cdot 1$ Weathering in the laboratory & \\
\hline $2 \cdot 2$ Secondary ion mass spectrometry & $4 \cdot 2$ Weathering in nature & \\
\hline 3 Environmental Particles 489 & 5 Conclusions & 496 \\
\hline \multirow{2}{*}{$\begin{array}{l}\text { 3.1 An example of a simple model for the peculiar } \\
\text { chemical composition of environmental surfaces: } \\
\text { adsorption of phosphate on iron oxides }\end{array}$} & 6 Acknowledgements & 496 \\
\hline & 7 References & 496 \\
\hline
\end{tabular}

\section{Introduction}

In nature, solids interact with their environment through their surfaces or, to put it in another way, the only contact between the environment and its solid constituents is by way of the interfaces between them. Hence, at any given moment, the chemical interaction between a solid and its environment is governed by the chemical composition of the surface of a solid, rather than by its bulk composition. If we extend the definition of "interface" to include the surfaces of any condensed matter, such as those formed by biological membranes, we can see the important roles of the surfaces and interfaces in environmental chemical processes. The interfaces are the devices that actually control the chemical flow in the environment. It therefore follows that the characterization of the surfaces of solid environmental samples is important. This is especially true for small particles, which have a high specific surface area. The earth is covered with layers of such small particles, in the form of sediment and soil. Thus, the effective microscopic surface area of the earth's surface is many orders of magnitude larger

$\doteqdot$ To whom correspondence should be addressed.

E-mail: seyamah@nies.go.jp than its geometrical area. This has a marked effect on the chemical and biological processes on the earth's surface. In this review, we present examples that show how selected surfaceanalytical techniques can be applied to characterizing environmental and geological solid surfaces.

\section{Surface-analytical Techniques for Environmental and Geological Samples}

The real development of surface-analytical techniques and their applications began in the 1970s. A variety of analytical instruments for probing surface layers (less than $10 \mathrm{~nm}$ in depth) have been developed, and have made it possible to study directly the surface physics and chemistry (crystal structure, elemental composition, chemical bonding state, etc.) of a solid sample. Among the many surface-analytical techniques, electron spectroscopy and secondary ion mass spectrometry (SIMS) are most commonly used in a variety of fields, including earth science and environmental science. The two major electron spectroscopic techniques that are normally applied to geological samples are X-ray photoelectron spectroscopy (XPS) and Auger electron spectroscopy (AES). Useful textbooks have been published on the principles, 
instrumentation, and applications of electron spectroscopy ${ }^{1}$ and SIMS. ${ }^{2,3}$ Several reviews have been written on the applications of XPS, ${ }^{4,5} \mathrm{AES},{ }^{6,7}$ and SIMS ${ }^{8,9}$ to mineral samples.

\section{2·1 Electron spectroscopy}

$\mathrm{X}$-ray photoelectron spectroscopy measures the kinetic-energy distribution of electrons (photoelectrons) emitted by X-ray irradiation from the core levels of elements constituting a solid sample. Typical X-ray sources used in XPS are $\mathrm{Al} \mathrm{K} \mathrm{K}_{\alpha}(1486.6$ $\mathrm{eV})$ and $\mathrm{Mg} \mathrm{K}_{\alpha}(1253.6 \mathrm{eV})$. The determination of the core electron binding energy, defined as the difference between the energy of the primary photon and the kinetic energy of the photoelectron, allows, in principle, the identification of elements. The emitted photoelectron leaves the atom in an unstable excited state, with a vacancy in its inner orbital. Auger transition is one of the processes by which the excited atom undergoes relaxation. In this process, an outer-orbital electron transfers to the vacancy, and the excess energy is released through the emission of another outer-orbital electron (Auger electron). Auger electron kinetic energy is also characteristic of a specific Auger transition of a specific atom. Auger electrons are measured in XPS together with photoelectrons. The X-ray beam penetrates deep into the sample, and causes the ejection of photoelectrons and Auger electrons. However, the emitted electrons may lose their kinetic energy through inelastic scattering while escaping from deeper parts of a sample to its surface. The background in X-ray photoelectron spectrum arises from these inelastically scattered electrons. Because the inelastic mean free-path of the photoelectron and Auger electron excited by soft X-rays in solids is short-typically on the order of nm-XPS and AES are surface sensitive, and all elements, other than $\mathrm{H}$ and $\mathrm{He}$, that are present in concentrations of more than $0.1-1 \%$ are detectable. For the XPS measurement on a sample having a flat surface, the spectral background can be reduced by using a total-reflection X-ray (TRXPS) or a grazingincidence X-ray (GIXPS), because of their shallow depths of penetration. ${ }^{10}$ In principle, electron spectroscopy is a nondestructive technique. Therefore, the characteristic features of the photoelectron and Auger electron spectra, such as the peak position (electron energy), satellite structure, and multiplet splitting, give information on the state of chemical bonding of the detected elements. The recent development of XPS instruments has enabled us to observe photoelectron images with a lateral resolution in the micrometer-to-submicrometer range using scanning or direct imaging techniques. ${ }^{11}$ In particular, photoelectron emission microscopy (PEEM), one of the direct imaging microscopes, is a promising technique for surface microscopy. ${ }^{12,13}$ A lateral resolution down to $20 \mathrm{~nm}$ has been achieved for X-ray PEEM (X-PEEM) with a synchrotronradiation photon source. ${ }^{14} \mathrm{X}$-ray PEEM has been applied to the analysis of geological samples. ${ }^{15}$

Conventional AES uses a high-intensity primary electron beam, which can be easily focused to fine spot of submicrometer-to-nanometer size, permitting the surface analysis of a selected local area on a sample. In addition, Auger electron images of the sample surface can be obtained by scanning a fine electron beam. This is known as scanning Auger microscopy (SAM). Many important geological and environmental samples are poor electrical conductors. Because the development of electric charge, arising from electron irradiation, is a serious problem in AES measurements, samples of such insulators should be mounted in a malleable metal foil, such as In, and the measurement conditions should be carefully tuned so as to minimize the sample charging. ${ }^{6}$ In recent years, an ion flood gun producing a low-energy positive ion beam, such as $\mathrm{Ar}^{+}$, has been used for negative-charge reduction. The positive sample charging in XPS due to photoelectron emission is not as troublesome as the negative charge-up in AES, and is effectively compensated by a combination of positive-ion and electron flood. ${ }^{16}$

\subsection{Secondary ion mass spectrometry}

Secondary ion mass spectrometry detects positive and negative ions emitted from a solid sample when the sample is bombarded by energetic primary ions, such as $\mathrm{O}^{-}$and $\mathrm{Cs}^{+}$. Primary ions sputter off the surface layer of the sample, and produce secondary species. Although most of the sputtered species are neutral, a small fraction of them are atomic or molecular ions (secondary ions). Secondary ion mass spectrometry permits elemental and isotopic analyses, and far surpasses electron spectroscopy in its sensitivity for elemental analysis. The isotopic composition of some elements, such as $\mathrm{Pb}$, is useful as an environmental tracer for determining the sources and pathways of pollution. The detection limit of SIMS, which depends on factors such as the choice of the instrument, the operating mode, and the measured element, is generally in the concentration range between parts per million (ppm) and parts per billion (ppb). However, the ionization probability is matrix sensitive, and the calculation of the elemental concentrations from secondary ion intensities is not straightforward. The large variation in the SIMS sensitivity for different elements is overcome, to some extent, by the use of different primary ion sources for electropositive and electronegative elements. As opposed to secondary ions, the yield of sputtered neutrals (the vast majority of emitted species) is not very sensitive to the matrix composition of the sample. Accordingly, the use of sputtered neutrals instead of ions for analysis can reduce the effects of the matrix on quantification, and could give a reliable quantitative analysis. In sputtered neutral mass spectrometry (SNMS), the neutral fraction sputtered by an ion beam from the sample surface is mass analyzed after it has been post-ionized by using a laser beam, electron impact, radio-frequency plasma, or the like. ${ }^{2}$

There are three general modes of operation for SIMS analysis, i.e. dynamic, static (low damage), and imaging SIMS. Dynamic SIMS uses a primary ion beam with a high current density to erode the sample surface rapidly. Since the surface layers are sputtered off one by one, the secondary ion intensities, recorded as a function of time, provide a depth profile of the elements in the sample. On the other hand, static SIMS is operated with a low primary ion current density (typically less than $1 \mathrm{nA} \mathrm{cm}^{-2}$ ). Because of a low sputtering rate and damage, static SIMS is useful for examining the uppermost surface of a sample. Two systems are available to observe secondary ion images with a lateral resolution of less than $1 \mu \mathrm{m}$. One is the ion microscope, in which a secondary ion image is projected directly onto a twodimensional detector. The other is the ion microprobe, in which a fine primary ion beam is scanned for secondary ion imaging, in the same way as in SAM. A three-dimensional image of a particular secondary ion is provided by the sequential accumulation of secondary ion images as the surface erosion progresses.

The surface of an insulating specimen builds up an electrical charge because of primary ion bombardment. Similar to AES, charging problems need to be overcome in SIMS analyses of geological samples. Common methods for reducing sample charging are to employ simultaneous electron flooding for positive charging, and to coat the sample surface with a thin layer of a metal, such as Au. The use of fast atom bombardment (FAB) instead of a primary ion beam is also 
effective in reducing the surface charging. ${ }^{17}$ There are several published examples of FAB-SIMS analysis of environmental samples. ${ }^{18-20}$ A method, which intentionally charges the sample surface, has also been used to suppress the detection of molecular ions in the mass spectra of insulating specimens (specimen isolation method). ${ }^{21}$

\section{Environmental Particles}

3.1 An example of a simple model for the peculiar chemical composition of environmental surfaces: adsorption of phosphate on iron oxides

Let us suppose that a soil contains only two particulate components of the same size, one of which constitutes one-tenth of the soil and is toxic to earthworms. If the toxic constituent is present as a surface coating on the more-common nontoxic particles, an earthworm living in such soil would be affected directly or indirectly through the soil solution, as much as it would be were it living in an environment of a $100 \%$ toxic substance. We can simulate such a system in the laboratory, and subject it to a surface analysis.

Phosphate is one of the major limiting factors for plant growth, and its bioavailability is important in raising agricultural productivity. On the other hand, there is a potential environmental risk that phosphates from fertilizers could cause the eutrophication of surface water. The adsorption and desorption processes of $\mathrm{PO}_{4}{ }^{3-}$ in soil are therefore of great concern for plant-nutrient management in farming. In a simple example, ${ }^{22}$ we mixed hematite $\left(\mathrm{Fe}_{2} \mathrm{O}_{3}\right)$ with sodium dihydrogen phosphate $\left(\mathrm{NaH}_{2} \mathrm{PO}_{4} \cdot 2 \mathrm{H}_{2} \mathrm{O}\right)$ at a $\mathrm{P} / \mathrm{Fe}$ atomic ratio of $1: 100$ to approximate the ratio in soil. When the mixture was examined by XPS, the P $2 p$ photoemission line was almost invisible compared with the Fe $2 p_{3 / 2}$ line (Fig. 1a). Successive suspension of the mixture in water and evaporation of the water resulted in a marked increase in the P $2 p$ photoelectron line (Fig. 1b). The surface $\mathrm{P} / \mathrm{Fe}$ atomic ratio was $1: 5,20$ times that of the bulk composition. This is consistent with the deposition of dissolved phosphate on insoluble ferric oxide particles as the water evaporates. Repeated washing of the mixture, followed by suspension and filtration, almost completely removed sodium from the particles, as monitored by the $\mathrm{Na} \mathrm{KL}_{23} \mathrm{~L}_{23}$ Auger electron line in XPS. The P $2 p$ line, however, remained at a significant intensity (Fig. 1c), which was attributed to chemisorbed phosphate. The apparent $\mathrm{P} / \mathrm{Fe}$ atomic ratio was $3: 100$, which was still larger than the ratio in the original mixture.

Bertrand et al. ${ }^{23}$ recently studied the surface adsorption of $\mathrm{PO}_{4}{ }^{3-}$ on goethite $[\mathrm{FeO}(\mathrm{OH})]$ particles, by imaging SIMS with two-dimensional scatter diagrams, i.e. by plotting the intensity of each pixel in one image versus that of the corresponding pixel in another image. After treatment of goethite with a $\mathrm{KH}_{2} \mathrm{PO}_{4}$ solution, they found a good linear correlation between the secondary ion intensities of $\mathrm{FeO}^{-}$and $\mathrm{P}^{-}$of the goethite samples, which suggests an even distribution of $\mathrm{PO}_{4}{ }^{3-}$ at the goethite surface, probably following an adsorption process. These examples of the adsorption of $\mathrm{PO}_{4}{ }^{3-}$ demonstrate the possible importance of a species as a surface component, even if it is marginal as a bulk constituent, and thus illustrate the importance of a technique that selectively analyzes surface and near-surface species.

\subsection{Fly ash}

The surface composition of coal fly ashes formed at electric power plants has been the subject of considerable environmental

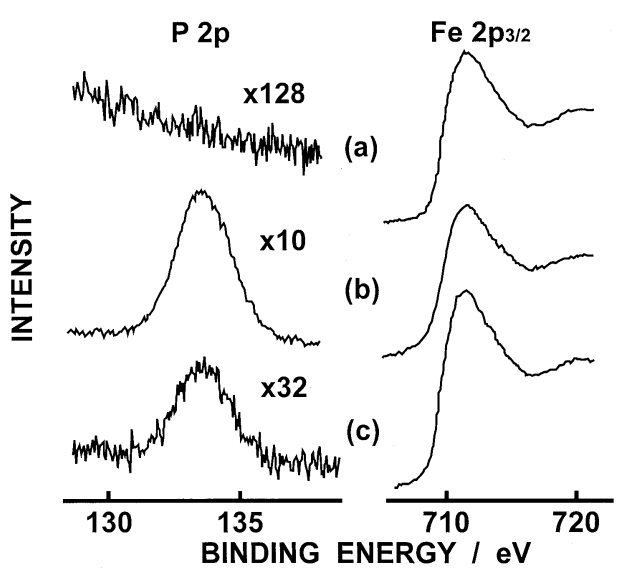

Fig. 1 P $2 p$ and $\mathrm{Fe} 2 \mathrm{p}_{3 / 2}$ photoelectron spectra for mixtures of ferric oxide (hematite) and sodium dihydrogen phosphate excited by $\mathrm{Al} \mathrm{K}_{\alpha}$ radiation: (a) simple mechanical mixture ( $\mathrm{P}: \mathrm{Fe}=1: 100)$; (b) dried aqueous suspension of the original mixture; (c) the suspension leached by water after removal of the aqueous phase by filtration, and dried. Multiplying factors on $\mathrm{P} 2 \mathrm{p}$ spectra are relative to the Fe $2 \mathrm{p}_{3 / 2}$ bands. (Reproduced, by permission, from Ref. 22. Copyright (1981): Elsevier Science).

concern, because volatile heavy metals tend to become concentrated in the surface layers of fly ash particles through volatilization-condensation mechanisms during the combustion process. Fly ash particles emitted into the atmosphere contain respirable-sized components. ${ }^{24}$ Once inhaled, the surface enrichment of toxic elements could enhance any possible adverse health effects. A higher concentration of volatile elements in the submicron particles has been observed, because the surface area-to-volume ratio of the fine particles is higher than that of coarser particles with sizes in the micron range. The surface compositions of coal fly ash, as determined by XPS analysis, showed surface enrichment of $\mathrm{S}, \mathrm{Ca}, \mathrm{Mg}$ and $\mathrm{P} .{ }^{25,26}$

As synchrotron radiation facilities have come into widespread use, X-ray absorption fine structure (XAFS) spectroscopy, with a synchrotron radiation photon source, has recently been used in the field of analytical chemistry. To examine the radial distribution of the chemical bonding states of elements, Kawai et al. ${ }^{27,28}$ developed a new, soft X-ray absorption spectroscopic technique, in which the X-ray absorption spectra are recorded simultaneously in two different modes, i.e. total electron yield (TEY) and X-ray fluorescence yield (XFY) measurements. The probing depth of TEY is shallower than $10 \mathrm{~nm}$, whereas that of XFY is deeper than $100 \mathrm{~nm}$. This technique therefore enables the simultaneous analysis of both the surface layer and the deeper parts of a sample. Sulfur K-edge spectra of coal fly ash samples were recorded by using this technique. ${ }^{28}$ The depthselective chemical state analysis showed that the major species of $\mathrm{S}$ in the surface layer was $\mathrm{S}^{6+}$. The sulfur should be oxidized to $\mathrm{SO}_{3}$ during the combustion process, and finally concentrated on the fly ash surface. However, the sulfur K-edge spectra taken by the XFY measurement indicated that $\mathrm{S}^{2-}$ remained within the cores of the fly ash particles.

Coal-fired power plants have problems relating to the storage and disposal of coal fly ash. In some cases, the coal fly ash is dumped into the ocean, and it is important to assess the potential availability to the marine environment of toxic elements released from the ash. To elucidate the reactions of coal fly ash particles with seawater, Brami et al. ${ }^{26}$ studied the surface chemical characteristics of coal fly ash retrieved after prolonged 


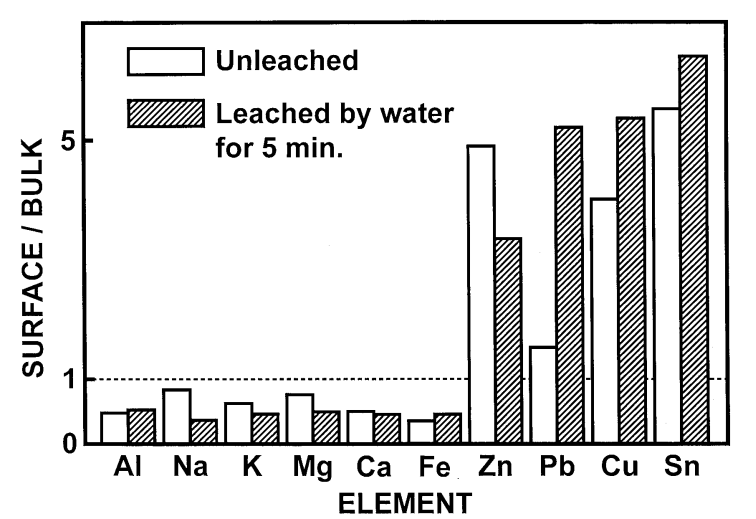

Fig. 2 (Surface) $)_{\mathrm{XPS}} /(\text { Bulk })_{\text {Total }}$ ratio of the concentration (in weight) of elements in a municipal incinerator fly ash. (Reproduced, by permission, from Ref. 29. Copyright (1989): Gordon and Breach Publishers)

immersion under deep-sea conditions. As expected, an XPS analysis of the retrieved coal fly ash showed a surface enrichment of $\mathrm{Na}$ and $\mathrm{Cl}$, which was attributed to the presence of sea salt. Compared with the surface chemical composition of the fresh coal fly ash, the surfaces of retrieved samples were depleted in $\mathrm{Si}, \mathrm{Ca}$ and $\mathrm{S}$. It is likely that the dissolution of the silicate phase under alkaline conditions results in the surface depletion of $\mathrm{Si}$. Low concentrations of $\mathrm{Ca}$ and $\mathrm{S}$ in the surface of the retrieved coal fly ash suggested the dissolution of $\mathrm{CaSO}_{4}$ from the surface. Because the depletion of $\mathrm{Ca}$ was more prominent than that of $\mathrm{S}$, it was necessary to take into account the dissolution of other $\mathrm{Ca}$ phases, such as the amorphous glassy phase. On the other hand, $\mathrm{Mg}$ was enriched on the surface of retrieved coal fly ash, indicating the precipitation of $\mathrm{Mg}(\mathrm{OH})_{2}$ (brucite). The formation of an $\mathrm{Mg}$-rich surface layer may inhibit the release of heavy metals from the fly ash surfaces.

In contrast to coal fly ash, little has been reported regarding fly ash from municipal waste incinerators. Since municipal wastes have a more complex chemical composition, which is difficult to regulate, fly ashes formed by their incineration should be presumed to contain higher concentrations of heavy metals. The ratio of the surface concentrations to the bulk concentrations of elements in a fly ash sample obtained from a municipal waste incinerator was determined by $\mathrm{XPS}^{29}$ (Fig. 2). This showed that heavy metals, such as $\mathrm{Zn}, \mathrm{Pb}, \mathrm{Cu}$, and $\mathrm{Sn}$, are concentrated in the surface layers at several times their bulk concentrations, ranging from $1320 \mathrm{mg} / \mathrm{kg}(\mathrm{Cu})$ to $19000 \mathrm{mg} / \mathrm{kg}$ ( $\mathrm{Zn})$. The surface-to-bulk concentration ratio of the major elements, the bulk concentrations of which were $3.5-9.5 \%$, was less than unity. The major elements were apparently diluted by heavy metals and other surface-enriched elements. The surfaceto-bulk concentration ratio of elements was also determined (Fig. 2) after the fly ash (1 g) had been subject to batch leaching by water $(10 \mathrm{ml})$ for $5 \mathrm{~min}$, a conventional procedure for evaluating the extent to which toxic elements are leached from solid-waste landfills. In contrast to water-soluble alkali, alkaline earth, and zinc compounds, the surface concentration of $\mathrm{Pb}$, which forms a sparingly soluble sulfate, increased remarkably. The $\mathrm{Pb} 4 \mathrm{f}$ and $4 \mathrm{~d}$ photoelectron binding energies of the leached sample were consistent with the deposition of $\mathrm{PbSO}_{4}$ onto the fly ash particles. In assessing the environmental behavior of fly ash particles, it is important to have information about the surface chemical composition and bonding state of the

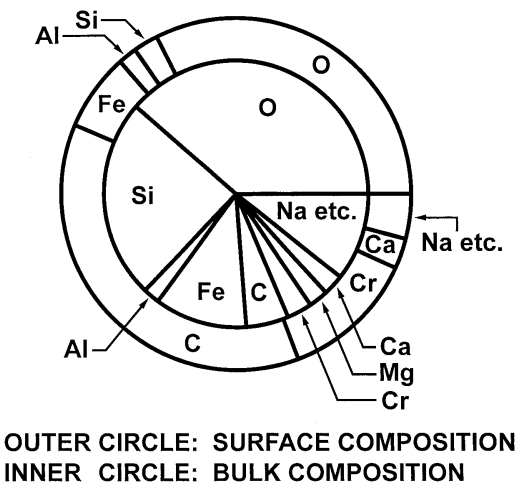

Fig. 3 Elemental composition of river sediment in weight percent. The inner circle represents the bulk composition and the outer circle represents the surface composition, as determined by XPS. (Reproduced, by permission, from Ref. 31. Copyright (1985): Pergamon Press Ltd.).

fly ash.

The adsorption of toxic metals $(\mathrm{Pb}, \mathrm{Zn}$, etc. $)$ and organic compounds [polycyclic aromatic hydrocarbons (PAH), etc.] onto surfaces of airborne particles is an important pathway for the distribution of these toxic substances in the environment. Zhu et al. ${ }^{30}$ analyzed particulate matter with a diameter of 2.5 $\mu \mathrm{m}\left(\mathrm{PM}_{2.5}\right)$ from air pollution using time-of-flight SIMS (TOFSIMS), XPS, and Fourier-transform infrared spectroscopy (FTIR). The high spatial resolution $(\sim 100 \mathrm{~nm})$ of TOF-SIMS allowed the surface analysis of individual particulates. Because both metallic elements and organic compounds are detectable, TOF-SIMS is useful for the surface characterization of samples having intricate chemical compositions.

\subsection{Sediment and soil}

A standard reference material (SRM) 1645 "River Sediment", issued by the U.S. National Bureau of Standards (NBS) - now the National Institute of Standards and Technology (NIST) exemplified a peculiar surface elemental composition for sediment particles collected from a polluted river. ${ }^{31}$ The bulk composition of matrix elements, such as $\mathrm{Si}, \mathrm{Fe}, \mathrm{Na}, \mathrm{Mg}, \mathrm{Ca}$, and $\mathrm{Al}$, was within what would be expected for ordinary soil or sediment samples, whereas the sediment contained a large amount of $\mathrm{Cr}(2.96 \%)$. The surface elemental composition determined by XPS was compared with the bulk one (Fig. 3). Chromium was present in apparently very high concentrations in the surface layers, whereas $\mathrm{Si}$ was depleted in these layers. The $\mathrm{Cr} / \mathrm{Si}$ atomic ratio at the surface was 46 times as large as the bulk ratio. In fact, the wide-scan X-ray photoelectron spectrum (binding energy range $0-1250 \mathrm{eV}$ ) showed that the sediment sample was more like chromium oxide mixed with organic carbon, with minor amounts of $\mathrm{Fe}, \mathrm{Ca}$, and $\mathrm{Mg}$. The silicon photoelectron ( $2 \mathrm{~s}$ or $2 \mathrm{p}$ ) binding energy provides useful information concerning the chemical speciation of $\mathrm{Si}^{32,33}$ The Si 2 s spectrum was measured as a silicon photoelectron line in this study. The Si 2 p spectrum is commonly preferred because it is sharper than the Si 2s line. However, the Al KLL Auger line excited by bremsstrahlung radiation overlaps the $\mathrm{Si} 2 \mathrm{p}$ line excited by $\mathrm{Al} \mathrm{K} \mathrm{K}_{\alpha}$ radiation. Aluminum is one of the important constituent elements of minerals, rocks, soils, and sediments. Therefore, we chose the Si 2s line for the study of such samples. Crushing the sediment particle by grinding to expose the inner part of the particles resulted not only in an increase of the Si $2 \mathrm{~s}$ line intensity relative to lines originating from the other 
elements, such as Cr 2p, but also in a shift of the Si 2s binding energy to a higher value of around $154 \mathrm{eV}$. The latter value is compatible with that of $\mathrm{Si}$ in silica, whereas the original, lower, binding energy is consistent with that of $\mathrm{Si}$ in clay minerals, which is considered to be the predominant surface Si species in the original particles. Such a distribution of $\mathrm{Cr}$ and $\mathrm{Si}$ suggests that $\mathrm{Cr}$ was introduced into the river as a pollutant, and deposited on the surface of the originally silica-rich sediment particles.

This kind of segregation of elements in sediment particles was also demonstrated for a natural depositional environment. ${ }^{34}$ In Lake Mashu, a caldera lake in eastern Hokkaido, Japan, hot springs at the bottom of the lake are a major source of dissolved elements. From the apparent surface composition determined by XPS, the elements in the sediment from the lake were divided into three groups according to their surface-to-bulk ratio of concentrations. The matrix elements, such as $\mathrm{Al}$, were slightly surface-depleted. The easily leachable elements, Na and $\mathrm{Ca}$, were significantly surface-depleted. Elements that were apparently surface-enriched included $\mathrm{Fe}, \mathrm{Mn}$, and $\mathrm{As},{ }^{35}$ suggesting that the dissolved $\mathrm{Mn}$ and Fe from the hot springs are oxidized to form insoluble oxides upon contact with oxic lake water, and precipitate onto the sediment, accompanied by the co-precipitation of As with hydrous ferric oxide.

X-ray photoelectron spectroscopy has also been used to examine organic matter in density-fractionated marine sediments. ${ }^{36}$ For the lightest fractions containing large amounts of organic matter, the surface concentration of organic carbon was the same as the bulk concentration. This suggests that the organic matter acts as a glue between the mineral particles, resulting in aggregate formation. On the other hand, for the heavier fractions, which were mostly mineral aggregates with minor amounts of associated organic matter, the organic matter was concentrated on the surfaces.

Surface chemical processes are important in soil science. For example, leaching (dissolution) and precipitation (deposition) of elements through a soil column forms a characteristic soil profile. Unfortunately, surface-analytical techniques have rarely been applied to real soil samples, presumably because the composition has been considered to be too complex to allow a quantitative explanation of the results. X-ray photoelectron spectroscopy is a suitable method among surface-analytical techniques for the analysis of soil, partly because it is less destructive than other techniques. We have applied XPS to assess the surface composition of soil particles taken from several horizons of Podzolic soils. ${ }^{37}$ Podzolic soil develops under forests in moist temperate or cool climates. It is acidic because of the input of organic acids. One of the important findings of this study was that the surface of the soil particles was enriched in $\mathrm{C}, \mathrm{N}$, and $\mathrm{Al}$. Carbon and nitrogen could be assigned to organic matter, and the larger surface $\mathrm{C}(\mathrm{N})$ concentration was associated with the higher $\mathrm{Al}$ concentration, strongly indicating the presence of Al-organic complexes as a coating over the surfaces of the soil particles. Such information on $\mathrm{Al}$ would be important in assessing the behavior of $\mathrm{Al}$ (mobilized) in soil under acidic deposition. Barr et al. ${ }^{38}$ also attempted to characterize soil samples by XPS analysis ( $\mathrm{Si} / \mathrm{Al}$ atomic ratio, $\mathrm{Si} 2 \mathrm{p}$ and $\mathrm{Al} 2 \mathrm{p}$ photoelectron binding energies, etc.), and pointed out that the structure of the photoelectron spectrum in the valence band region gives a clue as to the constituent minerals in the soil.

The information on the radial distribution and chemical speciation of a toxic element, such as a heavy metal, in contaminated soil particles is helpful in assessing the health and environmental risks associated with that element in soils.
Tingle et al..$^{39}$ applied XPS and SNMS to the surface analysis of soils from an area of active mining and smelting where $\mathrm{Cu}-\mathrm{Pb}-\mathrm{Zn}-\mathrm{Ag}-\mathrm{Au}$ ore had been mined. They found that the soil surfaces were contaminated with $\mathrm{Pb}$, and there was a correlation between the surface $\mathrm{Pb}$ levels and the soil $\mathrm{pH}$. Soils with a $\mathrm{pH}$ below 4 contained little or no $\mathrm{Pb}$ on grain surfaces, whereas soils with a $\mathrm{pH}$ above 4 showed abundant $\mathrm{Pb}$ on mineral surfaces. The $\mathrm{Pb}$-bearing surface layers on soil particles were estimated to be of the order of a few nanometers thick, by SNMS depth profiling. The lead $4 \mathrm{f}_{7 / 2}$ photoelectron binding energies of soil samples suggested that $\mathrm{Pb}$ was present as divalent $\mathrm{Pb}-\mathrm{O}$ and/or $\mathrm{Pb}-\mathrm{OH}$ species. An understanding of the surface chemistry and weathering of soils and minerals in areas where ore deposits occur is valuable for predicting the possible pollution problems from mining activity. In addition, it may be also useful in the exploration of underground deposits.

The direct detection of organic pollutants on environmental surfaces is an important analytical activity, because we can analyze samples without any tedious pretreatment. Static SIMS, a suitable analytical technique for identifying organic compounds adsorbed on a surface, was applied to detect the residues of various pesticides on soil particles, by using an $\mathrm{ReO}_{4}{ }^{-}$primary ion beam. ${ }^{40}$ The $\mathrm{ReO}_{4}{ }^{-}$primary particle provides an enhanced production of molecular secondary ions, and is advantageous when probing organic surface-adsorbates. More recently, SIMS with an ion trap mass spectrometer and $\mathrm{ReO}_{4}^{-}$ primary ion was used to analyze chemical-warfare agents (organosulfides, ${ }^{41,42}$ organophosphorus compound, ${ }^{43}$ and amines ${ }^{44}$ ) on soil particles. The ion trap mass spectrometer is capable of selective accumulation of secondary ions having a specific mass range. Once formed and isolated, the secondary ions can be collisionally dissociated to form fragment ions that are diagnostic of the organic molecule of interest, and are discriminated from the background signals in the mass spectra, which arise from the ubiquitous organic adsorbates present on the soil surface. This instrumental approach using ion trap SIMS is a promising surface-analytical technique for probing low concentrations of organic compounds adsorbed on environmental surfaces.

In sediment and soil, elements such as $\mathrm{Al}$ and $\mathrm{Fe}$ dissolve from, and precipitate onto, a solid phase, in a manner that depends on the condition of the ambient solution. The deposition often results in the formation of fine particles with an amorphous or poorly crystallized phase. Because of their large specific surface areas and inherent surface reactivities, these components are chemically active in the environment. One of these forms of particulate matter is naturally occurring ferrihydrite, a poorly crystallized form of hydrous ferric oxide. Singh et al..$^{45}$ examined the chemistry and mineralogy of ochre sediments containing goethite and ferrihydrite from acidic mine drainage. An X-ray photoelectron spectroscopic analysis of the sediment samples showed the presence of adsorbed $\mathrm{SO}_{4}{ }^{2-}$, which could be exchanged with other specifically adsorbed anions, such as $\mathrm{PO}_{4}^{3-}$. Fine particles of ferrihydrite could contribute to the $\mathrm{SO}_{4}{ }^{2-}$ adsorption, because of the high areas of the reactive surface. It is certain that ferrihydrite is one of the important constituent minerals for controlling the environmental chemistry in a mining area.

Ferrihydrite is also considered to be the precursor of hematite and goethite in natural systems, and is often associated with other components, notably silicate. ${ }^{46}$ It has been suggested that ferrihydrite can be partly stabilized by association with silicate and organic anions. X-ray photoelectron spectroscopy could be used to characterize the chemical state of silicate microscopically well-dispersed (or in the molecular state) in a 
ferrihydrite matrix. ${ }^{47}$ The $\mathrm{Fe} / \mathrm{Si}$ atomic ratio of naturally occurring siliceous ferrihydrite, as determined by XPS, approximated to, or was slightly larger than, the bulk ratio. This indicated that silicate was microscopically (on the scale of the photoelectron mean free-path of several nanometers) well dispersed in the ferrihydrite matrix. The Si 2s binding energy $(152.7-153.1 \mathrm{eV})$ was close to that of nesosilicates, such as olivine $\left[(\mathrm{Mg}, \mathrm{Fe})_{2} \mathrm{SiO}_{4}, 152.9-153.0 \mathrm{eV}^{48}\right]$, and was well below that of silicon dioxide, i.e. quartz $\left(154.4 \mathrm{eV}^{48}\right)$. Accordingly, the $\mathrm{SiO}_{4}{ }^{4-}$ tetrahedral unit was considered not to be significantly three-dimensionally polymerized. On the other hand, for ferrihydrite precipitated in the laboratory from a solution containing silicate, the XPS Fe/Si atomic ratio was smaller than the bulk one, and the Si 2 s binding energy $(154.1 \mathrm{eV})$ was higher, and close to that of quartz. These facts suggested that silica layers with three-dimensionally polymerized $\mathrm{SiO}_{4}{ }^{4-}$ units covered the outer surfaces of the ferrihydrite particles. Partially resolved double peaks in the $\mathrm{O} 1 \mathrm{~s}$ spectrum of the synthetic ferrihydrite were consistent with the segregation of the two oxide phases, ferrihydrite and silica. In natural processes, which often occur over a longer time span, a peculiar material phase may be formed, which is not easily produced in laboratory experiments. The identification of such unusual phases is one of the challenges in the chemical analysis of environmental samples.

\section{Chemical Weathering of Silicate Minerals}

The constituent minerals in rocks and soils are gradually decomposed through a variety of reactions, such as hydrolysis, hydration, oxidation, ion exchange, and adsorption. These reactions, taken together, are referred to as "chemical weathering", which plays a key role in the geochemical cycling of elements on the earth's surface. For example, the dissolution of minerals and rocks by slightly acidic natural water (containing dissolved carbon dioxide) has, over geological timescales, led to the formation and accumulation of soils. Because the rate of dissolution under acidic conditions increases with decreasing $\mathrm{pH}$, mineral weathering is accelerated by rainwater that has been acidified by oxides of sulfur and of nitrogen produced by the combustion of fossil fuels. Indeed, the widespread incidence of acid rain poses a serious environmental problem of global proportions. Chemical weathering takes place at the mineral surface/solution interface, and the process is strongly influenced by the structure and chemical composition of the mineral, as well as by the properties of the ambient solution (acidity, temperature, etc.). Surface-analytical techniques are useful in probing the mechanisms underlying chemical weathering, which is essentially a surface process.

As the major constituents of rocks, silicate minerals have received a great deal of attention in terms of their susceptibility to chemical weathering. Many studies concerning the chemical weathering of silicate minerals have been reported. The surface alteration of feldspars, ${ }^{49}$ pyroxenes,${ }^{50}$ and amphiboles ${ }^{50}$ by weathering and dissolution have been reviewed. Nevertheless, we still have no clear understanding of the surface alterations that occur during the dissolution of silicate minerals. Here, we describe the surface analysis of weathered silicates, focusing on the formation of an altered (depleted) surface layer through the preferential leaching of some elements from the mineral surface. Another interest in this section is the formation of a protective coating, such as a hydroxide deposited from the ambient solution onto the mineral surface. The surface alteration of silicate minerals weathered both in the laboratory
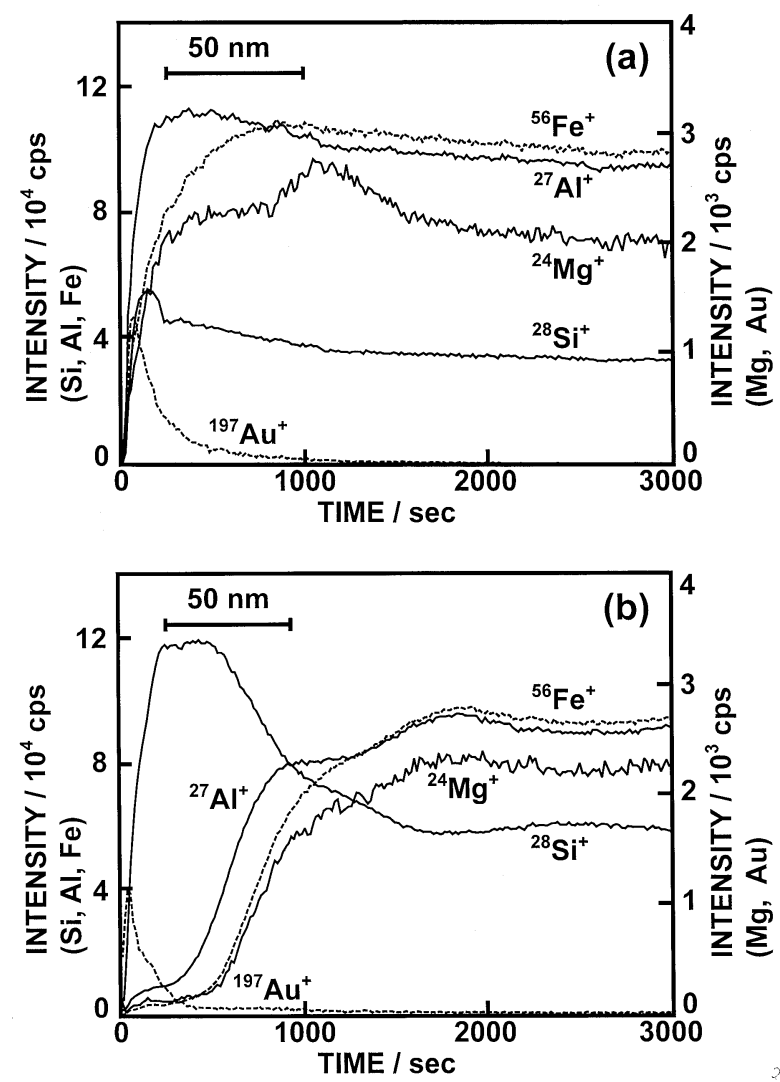

Fig. 4 Positive secondary ion depth profiles of biotite (a) before and (b) after acid dissolution $\left(0.05 \mathrm{~mol} \mathrm{l}^{-1} \mathrm{H}_{2} \mathrm{SO}_{4}\right)$ for 1 week. The samples were coated with a layer of $\mathrm{Au}$ and bombarded with an $\mathrm{O}^{-}$ primary ion. (Reproduced, by permission, from Ref. 51. Copyright (1998): A. A. Balkema).

and in nature will be described.

\subsection{Weathering in the laboratory}

The surface alteration of acid-leached biotite $\left[\mathrm{K}(\mathrm{Fe}, \mathrm{Mg})_{3} \mathrm{AlSi}_{3} \mathrm{O}_{10}(\mathrm{OH}, \mathrm{F})_{2}(\mathrm{Fe}>\mathrm{Mg})\right]$, a major rock-forming mineral in granite, was examined as a model for the chemical weathering of silicate minerals. ${ }^{51}$ A cleaved thin section of biotite was immersed in $0.05 \mathrm{~mol} \mathrm{l}^{-1} \mathrm{H}_{2} \mathrm{SO}_{4}$ for $1 \mathrm{~h}$ to 10 days with constant stirring, and then analyzed by XPS and SIMS. The positive secondary ion depth profiles of biotite samples, before and after acid treatment (Fig. 4), provided evidence for the formation of an altered surface layer. Compared with the original sample (Fig. 4a), the depth profile of the acid-treated mineral (Fig. 4b) showed a delay in the rise of the ${ }^{56} \mathrm{Fe}^{+}$and ${ }^{24} \mathrm{Mg}^{+}$signals, indicating that the altered surface layer was depleted in these elements. The ${ }^{56} \mathrm{Fe}^{+}$and ${ }^{24} \mathrm{Mg}^{+}$profiles of the acid-treated biotite were similar to each other. The biotite surface after acid dissolution was also depleted in $\mathrm{Al}$, but the depth of the depletion was less than that for the divalent cations, $\mathrm{Fe}$ and $\mathrm{Mg}$ (Fig. 4b). It would therefore appear that $\mathrm{Fe}$ and $\mathrm{Mg}$ are more susceptible to acid leaching than Al. In addition, the acid treatment caused an initial increase in the ${ }^{28} \mathrm{Si}^{+}$intensity (Fig. 4b), which later decreased to a value representative of the bulk mineral. The SIMS results clearly indicate preferential leaching of $\mathrm{Fe}, \mathrm{Mg}$, and $\mathrm{Al}$ from the surface layer of biotite, and simultaneous surface enrichment by $\mathrm{Si}$ during acid dissolution. After one week of acid treatment, the thickness of the altered surface layer was about $100 \mathrm{~nm}$. However, the thickness of the dissolved layer, deduced from the concentration of elements in 


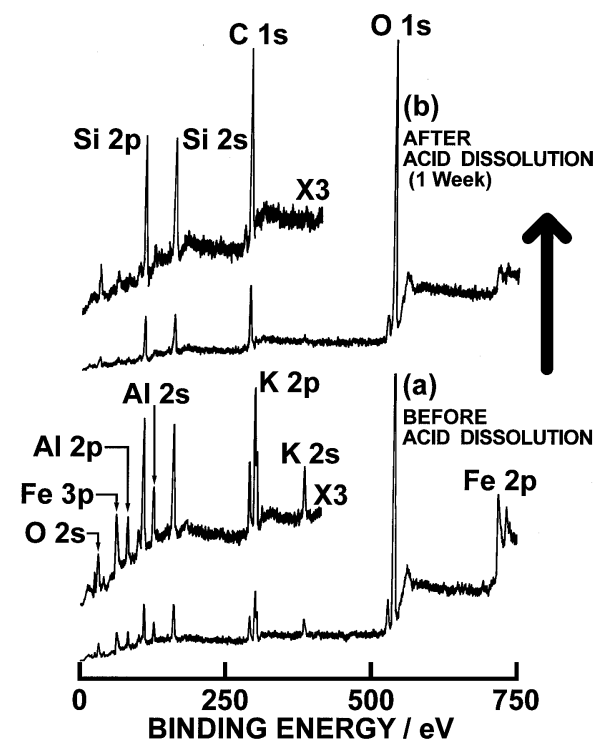

Fig. 5 X-ray photoelectron spectra of biotite excited by $\mathrm{Al} \mathrm{K}_{\alpha}$ radiation (a) before and (b) after acid dissolution $\left(0.05 \mathrm{~mol} \mathrm{l}^{-1} \mathrm{H}_{2} \mathrm{SO}_{4}\right)$ for 1 week. (Reproduced, by permission, from Ref. 51. Copyright (1998): A. A. Balkema).

the acid extract, was greater than that of the altered layer, indicating that all of the constituents of several layers, including $\mathrm{Si}$, were removed from the surface by the acid dissolution. The $\mathrm{K}^{+}$ion is held between the aluminosilicate layers, and would also be expected to be leached by acid treatment. However, the depth profile of the ${ }^{41} \mathrm{~K}^{+}$secondary ion did not provide clear evidence for the surface depletion of $\mathrm{K}$ in the biotite after acid dissolution. The ${ }^{41} \mathrm{~K}^{+}$intensity of the surface was often higher than that of the bulk, for both unleached and acid-leached samples. Alkali metals are known to become mobile in a sample during a SIMS analysis, as the result of sample charging. ${ }^{3}$ The surface enrichment of $\mathrm{K}$ may therefore be due to charge-induced migration of $\mathrm{K}^{+}$under $\mathrm{O}^{-}$bombardment (see the XPS results below).

The formation of an altered surface layer was confirmed by XPS (Fig. 5), although the Mg concentration was too low to be detected. ${ }^{51}$ For acid-leached biotite, the surface abundances of $\mathrm{Al}, \mathrm{Fe}$, and $\mathrm{K}$ relative to $\mathrm{Si}$ decreased with increasing reaction time. This observation was indicative of the preferential dissolution of $\mathrm{Al}, \mathrm{Fe}$, and $\mathrm{K}$, in keeping with the SIMS depth profiling. The Si $2 \mathrm{~s}$ and $\mathrm{O}$ 1s photoelectron binding energies of the original sample were $153.3 \mathrm{eV}$ and $531.3 \mathrm{eV}$, respectively. The corresponding spectra during acid treatment broadened and shifted to higher binding energies. After acid treatment for more than one week, the binding energies of both Si 2s (154.1 $154.6 \mathrm{eV})$ and $\mathrm{O} 1 \mathrm{~s}(532.5-533.1 \mathrm{eV})$ were comparable to those of silicon dioxides, such as quartz $(\mathrm{Si} 2 \mathrm{~s}=154.4 \mathrm{eV}$; O $1 \mathrm{~s}$ $=532.6 \mathrm{eV})$ and silica gel $(\mathrm{Si} 2 \mathrm{~s}=154.6 \mathrm{eV} ; \mathrm{O} 1 \mathrm{~s}=533.1 \mathrm{eV})$, suggesting the formation of $\mathrm{SiO}_{2} \cdot n \mathrm{H}_{2} \mathrm{O}$ on the mineral surface. Scanning electron microscopy (SEM) of acid-treated biotites showed surface fractures indicative of non-uniform dissolution, as reported for other silicate minerals. ${ }^{48,52,53}$

The laboratory weathering of feldspars has frequently been studied, because these are the most abundant constituents of igneous rocks, and are susceptible to weathering. X-ray photoelectron spectroscopy was previously used in the 1970s to assess the surface alteration of feldspar during dissolution, for example, by Petrovic et al. ${ }^{54}$ Recent studies on the surface alteration of plagioclase $\left[(\mathrm{Na}, \mathrm{Ca}) \mathrm{Al}\left(\mathrm{Al}, \mathrm{Si}_{)}\right) \mathrm{Si}_{2} \mathrm{O}_{8}\right]^{55-64}$ showed that preferential leaching of $\mathrm{Al}, \mathrm{Ca}$, and $\mathrm{Na}$ occurs during acid dissolution ( $\mathrm{pH} 1-4)$, resulting in the formation of an altered surface layer rich in $\mathrm{Si}$ (from over $10 \mathrm{~nm}$ to several hundreds of nanometers thick). As in biotite, $\mathrm{Ca}$ and $\mathrm{Na}$ were more susceptible to acid leaching than was $\mathrm{Al}$ in the aluminosilicate framework..$^{59,61,63,64}$ The hydrogen depth profile of acid-leached labradorite [a plagioclase with a $\mathrm{Ca} /(\mathrm{Ca}+\mathrm{Na})$ ratio of 0.5 - 0.7] showed that the hydrogen concentration in the surface layer was higher than that in the bulk, indicating the formation of a leached layer consisting of hydrated silicon dioxide. ${ }^{61}$ Based on quantitative SIMS depth profiling, the chemical composition of this layer was determined to be $\mathrm{SiO}_{1.8}(\mathrm{OH})_{0.4 \cdot}{ }^{61}$ Even after leaching in a weakly acidic solution $\left(5 \mu \mathrm{mol} \mathrm{l}^{-1} \mathrm{H}_{2} \mathrm{SO}_{4}\right), \mathrm{Ca}$ and $\mathrm{Na}$ were leached out from the surface layer of the plagioclase, whereas $\mathrm{Al}$ was slightly enriched at the surface. ${ }^{64}$ This suggested the formation of an altered surface layer, composed mainly of hydrous $\mathrm{Si}$ and $\mathrm{Al}$ oxides, during dissolution under slightly acidic conditions.

In plagioclase structures, the amount of $\mathrm{Al}$ varies in proportion to the relative amounts of $\mathrm{Ca}$ and $\mathrm{Na}$, so as to maintain electrical neutrality, i.e. the more $\mathrm{Ca}$, the greater is the amount of Al. Because the Al-O bond in aluminosilicate frameworks is weaker and is more easily cleaved than the $\mathrm{Si}-\mathrm{O}$ bond, plagioclase with a higher $\mathrm{Al}$ content is more susceptible to weathering. The altered surface layers of labradorite and bytownite [a plagioclase with a $\mathrm{Ca} /(\mathrm{Ca}+\mathrm{Na})$ ratio of $0.7-0.9$ ] that had been subjected to acid-leaching ( $\mathrm{pH} 3.5$ for 90 days) were thicker than that of sodium feldspar [albite $\left(\mathrm{NaAlSi}_{3} \mathrm{O}_{8}\right)$ ] that had been treated identically. ${ }^{55}$ Thus, for plagioclase feldspars, there seems to be a correlation between the thickness of the altered surface layer and its susceptibility to weathering. However, the altered surface layer of acid-leached calcium feldspar [anorthite $\left(\mathrm{CaAl}_{2} \mathrm{Si}_{2} \mathrm{O}_{8}\right)$ ] was thinner than that of acidleached labradorite ${ }^{60}$ despite the fact that anorthite has the fastest acid-dissolution rate among the plagioclase feldspars. ${ }^{49}$ Anorthite $[\mathrm{Al} /(\mathrm{Si}+\mathrm{Al})$ ratio $=0.5]$ contains more $\mathrm{Al}$ and less $\mathrm{Si}$ than labradorite $[\mathrm{Al} /(\mathrm{Si}+\mathrm{Al})$ ratio $=0.375-0.425]$, and also has a fully ordered framework structure in which the equal numbers of $\mathrm{Si}$ and $\mathrm{Al}$ in the tetrahedral site alternate in a regular fashion. As a result, there is less Si available in anorthite for the formation of a residual layer of polymerized silica. Instead, isolated $\mathrm{Si}(\mathrm{OH})_{4}$ is likely to be released into the solution when the $\mathrm{Al}-\mathrm{O}$ bonds in anorthite are cleaved during acid dissolution. To investigate the effect of the substitution of $\mathrm{Si}$ for $\mathrm{Al}$ in the three-dimensional $\mathrm{Si}-\mathrm{O}$ framework, three glasses with varying $\mathrm{Al}$ content-albite $\left(\mathrm{NaAlSi}_{3} \mathrm{O}_{8}, \mathrm{Al} /(\mathrm{Si}+\mathrm{Al})=0.25\right)$, jadeite $\left(\mathrm{NaAlSi}_{2} \mathrm{O}_{6}, \mathrm{Al} /(\mathrm{Si}+\mathrm{Al})=0.333\right)$, and nepheline $\left(\mathrm{NaAlSiO}_{4}\right.$, $\mathrm{Al} /(\mathrm{Si}+\mathrm{Al})=0.5)$ glasses-were synthesized and dissolved under acidic and basic conditions. ${ }^{65}$ This study showed that there are similarities in the dissolution behavior between plagioclase crystals and these glasses. The dissolution rate of the glasses at all $\mathrm{pH}$ values increased with increasing $\mathrm{Al}$ content. After acid leaching, the extent of $\mathrm{Al}$ depletion of the altered surface layer increased with increasing $\mathrm{Al} /(\mathrm{Si}+\mathrm{Al})$ ratio from 0.25 (albite glass) to 0.333 (jadeite glass), but then decreased in nepheline glass $[\mathrm{Al} /(\mathrm{Si}+\mathrm{Al})=0.5]$. The formation of thick altered layers depleted in $\mathrm{Na}$ and $\mathrm{Al}(210 \mathrm{~nm}$ thick) was observed on the surface of jadeite glass after reaction for more than $1000 \mathrm{~h}$ at $\mathrm{pH} 1$ or $\mathrm{pH} 2$.

Aqueous metal cations, such as $\mathrm{Al}^{3+}, \mathrm{Ca}^{2+}$, and $\mathrm{K}^{+}$, in the acidic solution retard the leaching (dissolution) of cations in labradorite, and suppress the development of an altered surface layer, because $\mathrm{H}^{+}$in the solution is prevented from penetrating into the surface layer of the mineral and releasing metal cations 
through cation-exchange reactions. ${ }^{57-59,62}$ On the other hand, anions such as $\mathrm{F}^{-}$and $\mathrm{C}_{2} \mathrm{O}_{4}{ }^{2-}$ (oxalate) can enhance the leaching of these cations, because of their ability to form aqueous complexes with $\mathrm{Ca}$ and $\mathrm{Al}$, thus giving rise to a thicker and more extensive leached layer. ${ }^{60,62}$

Adriaens et al..$^{53}$ studied the acid dissolution $\left(0.1 \mathrm{~mol} \mathrm{l}^{-1} \mathrm{HCl}\right.$ or $\mathrm{DCl}$ at $16-200^{\circ} \mathrm{C}$ ) of potassium feldspar [sanidine $\left(\mathrm{KAlSi}_{3} \mathrm{O}_{8}\right)$ ]. Because of its relatively low content of structural $\mathrm{Al}$, sanidine, like albite, is less susceptible to weathering than is plagioclase feldspar. Also, a thick altered layer does not form on the surface of acid-leached sanidine. However, when silica was added to the acid solution, Si dissolution was suppressed. This, and the preferential leaching of $\mathrm{Al}, \mathrm{K}$, and $\mathrm{Na}$ (a minor constituent), led to the formation of an Si-rich surface layer on sanidine. Depth profiling by SIMS indicated that the thickness of the altered surface layer (ranging from ten to several hundred nanometers) increased with the duration of leaching and with increasing temperature of the acid solution. When the solution contains silicic acid, hydrated silica may precipitate on the mineral surface. To distinguish between the leached layer and the precipitate on the surface, it is important to analyze both the mineral surface and the reactant solution after acid treatment. Teng et al. ${ }^{66}$ applied in situ atomic force microscopy (AFM) and X-ray reflectivity to probe directly the evolution of the dissolution of the (001) cleavage surface of another potassium feldspar, orthoclase $\left(\mathrm{KAlSi}_{3} \mathrm{O}_{8}\right)$, and demonstrated the utility of these analytical techniques for measuring nanometer-scale structures and face-specific dissolution rates on single crystals. Their measurements showed that orthoclase dissolution is controlled by at least two separate surface reactions. At acidic $\mathrm{pH}$ values, the dominant mechanism is active across the entire surface, and results in etch pit formation and roughening of the terrace area, whereas at alkaline $\mathrm{pH}$ values, the dominant mechanism is active primarily at steps and other defects, and does not change the local roughness, structure or stoichiometry of the surface. In the same manner as for acid-treated sanidine, no thick leached layer was formed, but thin coatings having a thickness of only a single unit cell were observed on an orthoclase surface under acidic conditions. Chen et al. ${ }^{67}$ used angle-resolved XPS to investigate the surface alteration of polished albite single crystals treated with $\mathrm{HCl}$ solutions at $\mathrm{pH}$ 2.9 at 5,50 and $90^{\circ} \mathrm{C}$. In contrast to the dissolution of sanidine in an acid solution containing added silica, ${ }^{53}$ the extent to which $\mathrm{Na}$ and $\mathrm{Al}$ were leached from the surface of albite decreased as the solution temperature increased. This was explained in terms of competition between dissolution of the surface layer and diffusion of $\mathrm{Al}$ and $\mathrm{Na}$ through the leached layer into solution. ${ }^{67}$ Thus, with increasing temperature, the dissolution rate of the altered surface layer increases more rapidly than the rate of diffusion, resulting in a decrease in the thickness of the leached layer. ${ }^{67}$

Similar Si-rich altered layers were also observed on the surfaces of acid-leached olivines, ${ }^{48,68-70}$ pyroxenes, ${ }^{68,71,72}$ and amphibole [tremolite, $\left.\mathrm{Ca}_{2}(\mathrm{Mg}, \mathrm{Fe})_{5} \mathrm{Si}_{8} \mathrm{O}_{22}(\mathrm{OH})_{2}(\mathrm{Mg}>\mathrm{Fe})\right],{ }^{72}$ because of preferential leaching of $\mathrm{Mg}, \mathrm{Fe}$, and $\mathrm{Ca}$. The thickness of altered surface layers, deduced from XPS analyses, was $20 \mathrm{~nm}$ for olivine, ${ }^{69}$ and less than a few nanometers for pyroxenes $^{68,72}$ and tremolite, ${ }^{72}$ i.e. it was less than that of acidleached biotite and plagioclase, as described above. The treatment of Fe-rich minerals (olivine and pyroxene) with a solution containing dissolved oxygen at $\mathrm{pH} 6$ led to the oxidation of $\mathrm{Fe}^{2+}$ to $\mathrm{Fe}^{3+}$ and the formation of hydrated ferric oxide on the mineral surface. ${ }^{68}$

A resonant nuclear reaction analysis (RNRA) was used to obtain hydrogen depth profiles of acid-leached silicate minerals. ${ }^{69,71}$ This technique is based on the resonant $\alpha-\gamma$ (helium and $\gamma$-rays) reaction between ${ }^{1} \mathrm{H}$ and ${ }^{15} \mathrm{~N}$ (resonance energy $=6.4 \mathrm{MeV}),{ }^{69,71}$

$$
{ }^{15} \mathrm{~N}+{ }^{1} \mathrm{H} \longrightarrow{ }^{12} \mathrm{C}+{ }^{4} \mathrm{He}+4.43 \mathrm{MeV}(\gamma \text {-rays }) .
$$

A depth profile of $\mathrm{H}$ can be obtained by bombarding a mineral sample with ${ }^{15} \mathrm{~N}$ of variable energy, and recording the $\gamma$-ray yield as a function of the ${ }^{15} \mathrm{~N}$ energy. The depth profiles for acid-leached diopside ${ }^{71}$ and olivine ${ }^{69}$ showed a high concentration of $\mathrm{H}$ at depths of up to $100-200 \mathrm{~nm}$, indicating the penetration of $\mathrm{H}$ (water) into the mineral during acid dissolution. On the other hand, during dissolution under alkaline conditions ( $\mathrm{pH} 12), \mathrm{H}$ was only concentrated within a region of less than $20 \mathrm{~nm}$ thick on the surface of olivine. ${ }^{69}$

In addition to affecting the $\mathrm{pH}$ of the soil solution, organic acids secreted by soil microorganisms, such as bacteria and fungi, can form complexes with metal ions in solution and on mineral surfaces. By promoting or inhibiting the dissolution process, soil microbes play an important role in the biological weathering of minerals. An XPS study on bacteria-enhanced mineral dissolution showed that bacteria (Arthrobacter species) capable of exuding a catecholate siderophore could accelerate the release of $\mathrm{Fe}$ from hornblende $\left[\mathrm{NaCa}_{2}(\mathrm{Mg}, \mathrm{Fe}, \mathrm{Al})_{5}(\mathrm{Si}, \mathrm{Al})_{8} \mathrm{O}_{22}(\mathrm{OH})_{2}\right]$ without measurably affecting the $\mathrm{Al}$ release, giving rise to an Fe-depleted surface layer. ${ }^{73}$ Kalinowski et al. ${ }^{73}$ inferred that the enhanced Fe release was caused by Fe-siderophore complexation at the mineral surface.

We examined the surface alteration of rock samples during acid dissolution, and confirmed the formation of an Si-rich layer. ${ }^{74}$ The acid dissolution of a rock consisting of feldspars reflected the behavior of its major constituents, i.e. orthoclase and albite. On the other hand, the dissolution behavior of an olivine-rich rock (dunite) was different from that of forsterite $\left(\mathrm{Mg}_{2} \mathrm{SiO}_{4}\right)$, its major mineral constituent. In this instance, the minor constituents of the rock sample appeared to have a controlling influence on the dissolution process.

According to the various studies described above, the dissolution of aluminosilicate minerals under highly acidic conditions proceeds as follows (Fig. 6). Initially, there is an exchange of $\mathrm{H}^{+}$in solution for charge-balancing cations, such as $\mathrm{Ca}^{2+}$ and $\mathrm{Na}^{+}$in plagioclase feldspars, by means of which the negative charge of the aluminosilicate network can be neutralized, resulting in the formation of a cation-exchange zone at the mineral surface. Subsequent removal of the chargebalancing cations and adsorption of $\mathrm{H}^{+}$cause the $\mathrm{Si}-\mathrm{O}$ and $\mathrm{Al}-\mathrm{O}$ bonds in the aluminosilicate framework (structure) to weaken, leading to their hydrolysis,

$$
\equiv \mathrm{Si}-\mathrm{O}-\mathrm{Al} \equiv+\mathrm{H}_{2} \mathrm{O} \longrightarrow \equiv \mathrm{Si}-\mathrm{OH}+\mathrm{HO}-\mathrm{Al} \equiv .
$$

Because the Al-O bond is more readily hydrolyzed than the $\mathrm{Si}-\mathrm{O}$ bond, the formation of a cation-exchange zone is followed by the release of tetrahedrally coordinated $\mathrm{Al}^{3+}$ from the aluminosilicate framework. As a result, the framework disintegrates, and an altered layer rich in $\mathrm{Si}$ (hydrated silicon dioxide, $\mathrm{SiO}_{2} \cdot n \mathrm{H}_{2} \mathrm{O}$ ) forms at the mineral surface. The release of Si from the altered surface layer into solution is the ratelimiting step. The overall dissolution of silicate minerals proceeds through these steps. Hydrogen ions can penetrate deeply into the mineral, and charge-balancing cations can diffuse through the altered layer into solution. The thickness of the Si-rich altered layer is therefore determined by both the rates of dissolution of $\mathrm{Si}$ and leaching of the charge-balancing cation. 


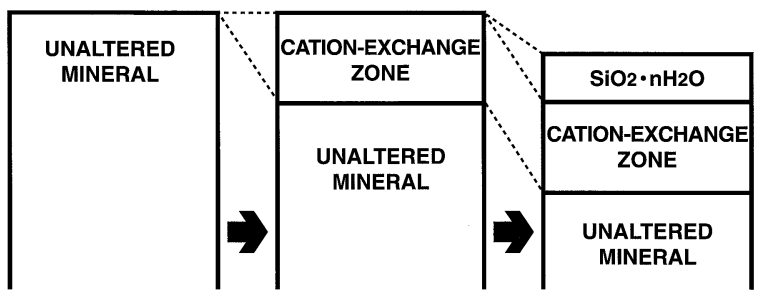

Fig. 6 Process of aluminosilicate mineral dissolution in acidic solution.

This layer becomes thicker as the rate of dissolution of $\mathrm{Si}$ decreases and the rate of leaching of the charge-balancing cation increases.

Based on this dissolution model, the diffusion coefficient and activation energy of diffusion can be determined from the variation in thickness of the altered surface layer, as a function of the reaction time and the temperature.53,63 For example, the activation energy of diffusion of $\mathrm{K}$ through the altered surface layer was estimated to be $1790 \mathrm{~J} \mathrm{~mol}^{-1}$ for the acid-leached sanidine..$^{53}$ The diffusion coefficients of $\mathrm{Al}$ and $\mathrm{Ca}$ in the leaching zone of acid-treated labradorite were calculated to be $2.5 \times 10^{-17}$ and $4.0 \times 10^{-17} \mathrm{~cm}^{2} \mathrm{~s}^{-1}$, respectively. ${ }^{63}$ It is worthwhile to obtain quantitative information on dissolution mechanisms from surface-analytical data, and to assess this information in terms of its significance to the chemical weathering process.

\subsection{Weathering in nature}

Only a limited number of reports are available on the surface alteration of minerals during natural weathering. Nesbitt and Muir $^{75}$ obtained SIMS depth profiles of naturally weathered plagioclase samples from a 10000-year-old till. In contrast to those of laboratory-weathered (acid-leached) minerals, these profiles showed a $30-80 \mathrm{~nm}$ thick surface layer that was depleted in $\mathrm{Si}$, but enriched in $\mathrm{Al}$ (Fig. 7). Although a layer of crystalline precipitates was not detected, an Al-rich surface layer may have formed because $\mathrm{Al}$ leaching was suppressed by the presence of dissolved $\mathrm{Al}$ in the soil solution. The SIMS depth profiles of naturally weathered biotite samples showed the formation of an altered layer $(<60 \mathrm{~nm})$ at the surface, which was slightly enriched in $\mathrm{Al}$ and $\mathrm{Si}^{76}$ This observation for naturally weathered biotite is different from that for biotite dissolved in acidic solution in the laboratory, which showed a surface layer depleted in $\mathrm{Fe}, \mathrm{Mg}$, and $\mathrm{Al},{ }^{51}$ as already described. In investigating the products of naturally weathered potassium feldspar, Kawano and Tomita ${ }^{77}$ did not find a leached layer, but detected a surface precipitate of amorphous aluminum hydroxide with fibrous and spherical particle morphology. They suggested that this material could be transformed into a crystalline phase, such as gibbsite $\left[\mathrm{Al}(\mathrm{OH})_{3}\right]$ or halloysite $\left[\mathrm{Al}_{2} \mathrm{Si}_{2} \mathrm{O}_{5}(\mathrm{OH})_{4}\right]$, as weathering proceeds. As mentioned above, the formation of an Al-enriched phase was observed on a plagioclase surface during dissolution under slightly acidic conditions. ${ }^{64}$ Boehmite $[\mathrm{AlO}(\mathrm{OH})]$ nucleated at an orthoclase surface in the form of $130 \mathrm{~nm}$ thick and $>1 \mu \mathrm{m}$ wide crystals after acid treatment for 11 months at $\mathrm{pH} 2$ and $95^{\circ} \mathrm{C} .{ }^{66}$ These results of feldspar dissolution in the laboratory compare favorably with the surface enrichment of $\mathrm{Al}$ observed for naturally weathered feldspars.

On the other hand, Berner and Schott ${ }^{52}$ observed a thin (less than a few nanometers thick) altered surface layer, depleted in $\mathrm{Ca}$ and $\mathrm{Mg}$, on grains of partially weathered pyroxenes and

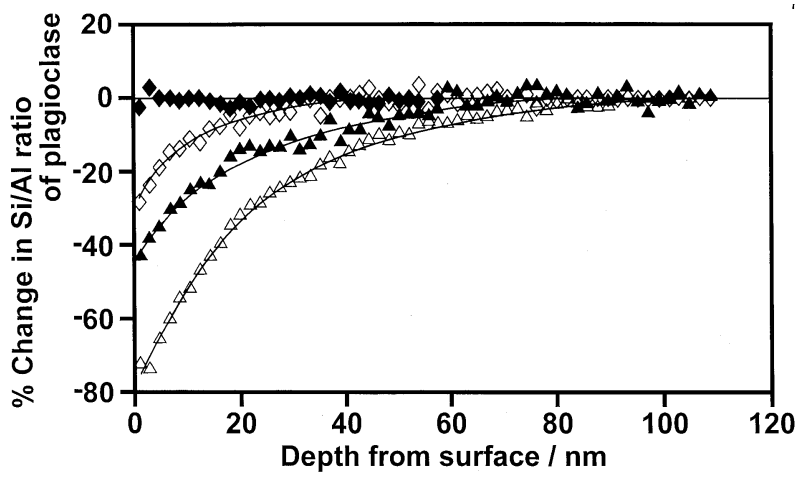

Fig. 7 Percentage change in the SIMS ${ }^{28} \mathrm{Si} /{ }^{27} \mathrm{Al}$ ratio of the three weathered plagioclase grains as a function of depth from the surface of each grain. $\mathrm{Si} / \mathrm{Al}$ ratios are normalized to the values for the unweathered interior of the same grains. Symbols: $\bullet$, fresh plagioclase; $\diamond, \boldsymbol{\Delta}, \Delta$, three samples of weathered plagioclase grains. (Reproduced, by permission, from Ref. 75. Copyright (1988): Nature Publishing Group).

amphibole (hornblende) from soil, suggesting that the weathering process was similar to acid dissolution in the laboratory. The depth profile of naturally weathered hornblende, determined by a combination of AES and sputtering with an argon ion beam, showed formation of a thick (up to $120 \mathrm{~nm}$ ) altered surface layer depleted in $\mathrm{Ca}$ and $\mathrm{Mg}$, but enriched in $\mathrm{Si}, \mathrm{Al}$, and $\mathrm{Fe}^{78}$ No strong chemical change was observed on the surface of naturally weathered zircon $\left(\mathrm{ZrSiO}_{4}\right)$ grains. $^{79}$

To elucidate the mechanism of feldspar weathering in an acidic soil, Nugent et al. ${ }^{80}$ buried albite (90 mol\% albite and 10 mol\% anorthite) tablets in the B horizon [a layer of accumulation (illuviation) of leached material] of a Spodosol for 0.5 - 3.5 years, and examined the resulting surface alteration, by means of AFM, XPS, SIMS and other analytical techniques. At the depth of burial, the soil pore waters ranged in $\mathrm{pH}$ from 4.9 to 5.6 (average, 5.1), and were undersaturated with respect to all feldspars, but supersaturated relative to kaolinite. The depletion of $\mathrm{Al}$ and $\mathrm{Na}$ was observed at the surface of sample buried for 6 months (initial stage of weathering). However, the surfaces of samples that had been buried for longer periods were enriched in $\mathrm{Al}$, arising from the precipitation of a patchy coating of crystalline (kaolinite) and amorphous hydrous aluminosilicate. The particles of this discrete coating ranged in size from nanometers to millimeters, and in thickness from about 5 to $1000 \mathrm{~nm}$. The coating might partially inhibit further dissolution. An X-ray photoelectron spectroscopic analysis of a hornblende disk after 21 days of burial in a Spodosol also showed surface enrichment in $\mathrm{Fe}$ and $\mathrm{Al}$, probably associated with the formation of an amorphous $\mathrm{Fe} / \mathrm{Al}$ oxyhydroxide precipitate. $^{73}$

This summary indicates that the mechanisms of mineral dissolution under most laboratory conditions (acid dissolution) are not generally applicable to weathering in nature. Differences in the thickness and chemical composition of the altered surface layer between acid-leached and naturally weathered minerals may be ascribed to differences in the temperature, acidity, dissolved components, and ionic strength of the reactant solution. Cations dissolved in soil solutions should inhibit the formation of a thick siliceous leached layer on silicate mineral particles in soils. ${ }^{58}$ The surface enrichment by $\mathrm{Al}$, reported in some studies, presumably arises from the suppression of Al leaching, and/or the precipitation of an Al- 
rich phase, such as a hydroxide, from solutions with a moderate $\mathrm{pH}$. It should be noted that $\mathrm{Fe} / \mathrm{Al}$ oxides are common ultimate residues in the natural weathering of soil. Although weathering under laboratory and field conditions may proceed in a similar manner during the early stages, the formation of an Al-rich surface layer would affect the mineral dissolution over geological timescales. Natural weathering rates of silicate minerals are some orders of magnitude lower than the laboratory dissolution rates. ${ }^{81}$ A protective coating, such as an Al-rich surface layer, is likely to inhibit mineral dissolution, contributing to this discrepancy between the weathering rates measured in nature and in the laboratory.

More surface-analytical data on naturally weathered minerals of known history are required in order to elucidate the mechanisms of natural weathering of silicate minerals. Similarly, information is needed on the surface alteration of minerals treated with solutions containing inorganic and organic substances, simulating the complex systems present in nature. Mineral dissolution proceeds non-uniformly at sites associated with crystal imperfections and structural defects, which are preferentially decomposed. As a result, pits and fractures commonly develop on the surface of mineral grains. In addition, the mineral surface is often unevenly coated with material precipitated from the ambient solution during natural weathering. The assessment of non-uniform dissolution and precipitation requires the application of microscale surfaceanalytical techniques, such as SIMS and AFM, to weathered samples (analyzed area $\leqq 1 \mu \mathrm{m}^{2}$ ). Although AFM has been useful in revealing the fine structure of mineral surfaces, ${ }^{66,80}$ this method has not been widely applied to the analysis of weathered minerals. X-ray photoelectron microscopy ${ }^{11}$ is another versatile technique for characterizing the surface heterogeneity of weathered minerals.

\section{Conclusions}

Surface analysis is essential for evaluating heterogeneous environmental and geological samples. A combination of XPS and SIMS, which are general methods for surface analysis applicable to a wide range of samples, is especially advantageous for the surface characterization of environmental samples having intricate microstructures. The utility of synchrotron radiation as a powerful photon source has made surface-analytical techniques using photon excitation, such as XPS and XAFS, more valuable tools for probing surface chemistry. The recent development of instrumental analysis has also enabled microscopic surface analyses to be performed. Surface characterization by the use of various analytical techniques will facilitate a precise understanding of the chemical processes at the surfaces of various solid materials in nature.

\section{Acknowledgements}

This work was financially supported in part by Grants-in-Aid for Scientific Research (C) (2) No. 10640477 and 13680613 from Japan Society for the Promotion of Science. We thank Dr. B. K. G. Theng for his helpful advice in the preparation of the manuscript.

\section{References}

1. D. Briggs and M. P. Seah (ed.), "Practical Surface Analysis, 2nd ed., Vol. 1: Auger and X-Ray Photoelectron Spectroscopy", 1990, John Wiley \& Sons, Chichester.

2. D. Briggs and M. P. Seah (ed.), "Practical Surface Analysis, 2nd ed., Vol. 2: Ion and Neutral Spectroscopy", 1992, John Wiley \& Sons, Chichester.

3. A. Benninghoven, F. G. Rüdenauer, and H. W. Werner, "Secondary Ion Mass Spectrometry, Basic Concepts, Instrumental Aspects, Applications and Trends", 1987, John Wiley \& Sons, New York.

4. D. L. Cocke, R. K. Vempati, and R. H. Loeppert, in "Quantitative Methods in Soil Mineralogy", ed. J. E. Amonette and L. W. Zelazny, 1994, Soil Science Society of America, Madison, 205.

5. E. Paterson and R. Swaffield, in "Clay Mineralogy; Spectroscopic and Chemical Determinative Methods", ed. M. J. Wilson, 1994, Chapman \& Hall, London, 226.

6. D. W. Mogk, Rev. Geophys., 1990, 28, 337.

7. H. W. Nesbitt and A. R. Pratt, Can. Mineral., 1995, 33, 243.

8. N. D. MacRae, Can. Mineral., 1995, 33, 219.

9. W. Shotyk and J. B. Metson, Rev. Geophys., 1994, 32, 197.

10. J. Kawai, S. Hayakawa, Y. Kitajima, and Y. Gohshi, Anal. Sci., 1995, 11, 519.

11. G. A. Garwood, Jr., in "The Handbook of Surface Imaging and Visualization”, ed. A. T. Hubbard, 1995, CRC Press, Boca Raton, 687.

12. M. E. Kordesch, in "The Handbook of Surface Imaging and Visualization”, ed. A. T. Hubbard, 1995, CRC Press, Boca Raton, 581.

13. G. De Stasio, M. Capozi, G. F. Lorusso, P. A. Baudat, T. C. Droubay, P. Perfetti, G. Margaritondo, and B. P. Tonner, Rev. Sci. Instrum., 1998, 69, 2062.

14. G. De Stasio, L. Perfetti, B. Gilbert, O. Fauchoux, M. Capozi, P. Perfetti, G. Margaritondo, and B. P. Tonner, Rev. Sci. Instrum., 1999, 70, 1740.

15. G. De Stasio, B. Gilbert, B. H. Frazer, K. H. Nealson, P. G. Conrad, V. Livi, M. Labrenz, and J. F. Banfield, J. Electron. Spectrosc. Relat. Phenom., 2001, 114 - 116, 997.

16. J. B. Metson, Surf. Interface Anal., 1999, 27, 1069.

17. H. Seyama and M. Soma, Surf. Interface Anal., 1990, 15, 289.

18. H. Seyama, J. S. Edmonds, M. J. Moran, Y. Shibata, M. Soma, and M. Morita, Experientia, 1991, 47, 1193.

19. H. Seyama, Y. Soma, M. Soma, S. Takao, T. Sakurai, and S. Tagami, Fresenius' J. Anal. Chem., 1991, 341, 619.

20. H. Seyama, Appl. Surf. Sci., 2003, 203 - 204, 745.

21. J. B. Metson, G. M. Bancroft, N. S. McIntyre, and W. J. Chauvin, Surf. Interface Anal., 1983, 5, 181.

22. M. Soma and H. Seyama, Appl. Surface Sci., 1981, 8, 478.

23. I. Bertrand, N. Grignon, P. Hinsinger, G. Souche, and B. Jaillard, Scanning, 2001, 23, 279.

24. R. W. Linton, D. T. Harvey, and G. E. Cabaniss, in "Analytical Aspects of Environmental Chemistry", ed. D. F. S. Natusch and P. K. Hopke, 1983, Wiley-Interscience, New York, 137.

25. M. Bellotto, C. Boni, A. Caridi, E. Cereda, C. Chemelli, G. M. Braga Marcazzan, F. Parmigiani, M. Scagliotti, and B. Bellagamba, Mat. Res. Soc. Symp. Proc., 1990, 178, 45.

26. Y. Brami, B. Herut, A. Shemesh, and H. Cohen, Environ. Sci. Technol., 1999, 33, 276.

27. J. Kawai, H. Adachi, S. Hayakawa, S. Y. Zhen, K. 
Kobayashi, Y. Gohshi, K. Maeda, and Y. Kitajima, Spectrochim. Acta, Part B, 1994, 49, 739.

28. J. Kawai, S. Hayakawa, F. Esaka, S. Zheng, Y. Kitajima, K. Maeda, H. Adachi, Y. Gohshi, and K. Furuya, Anal. Chem., 1995, 67, 1526.

29. M. Soma, A. Tanaka, and H. Seyama, Intern. J. Environ. Anal. Chem., 1989, 36, 103.

30. Y.-J. Zhu, N. Olson, and T. P. Beebe, Jr., Environ. Sci. Technol., 2001, 35, 3113.

31. M. Soma, H. Seyama, and K. Okamoto, Talanta, 1985, 32 , 177.

32. H. Seyama and M. Soma, J. Chem. Soc., Faraday Trans. 1, 1985, $81,485$.

33. H. Seyama and M. Soma, "Application of X-Ray Photoelectron Spectroscopy to the Study of Silicate Minerals", 1988, Research Report from the National Institute for Environmental Studies, Japan, No. 111.

34. A. Tanaka, H. Seyama, and M. Soma, Geochem. J., 1994, $28,289$.

35. M. Soma, A. Tanaka, H. Seyama, and K. Satake, Geochim. Cosmochim. Acta, 1994, 58, 2743.

36. T. S. Arnarson and R. G. Keil, Org. Geochem., 2001, 32, 1401.

37. G. Yuan, M. Soma, H. Seyama, B. K. G. Theng, L. M. Lavkulich, and T. Takamatsu, Geoderma, 1998, 86, 169.

38. T. L. Barr, E. E. Hoppe, S. Hardcastle, and S. Seal, J. Vac. Sci. Technol., A, 1999, 17, 1079.

39. T. N. Tingle, R. S. Borch, M. F. Hochella, Jr., C. H. Becker, and W. J. Walker, Appl. Surf. Sci., 1993, 72, 301.

40. J. C. Ingram, G. S. Groenewold, A. D. Appelhans, J. E. Delmore, J. E. Olson, and D. L. Miller, Environ. Sci. Technol., 1997, 31, 402.

41. G. S. Groenewold, A. D. Appelhans, J. C. Ingram, G. L. Gresham, and A. K. Gianotto, Talanta, 1998, 47, 981.

42. G. L. Gresham, G. S. Groenewold, A. D. Appelhans, J. E. Olson, M. T. Benson, M. T. Jeffery, B. Rowland, and M. A. Weibel, Int. J. Mass Spectrom., 2001, 208, 135.

43. G. S. Groenewold, A. D. Appelhans, G. L. Gresham, J. E. Olson, M. T. Jeffery, and J. B. Wright, Anal. Chem., 1999, $71,2318$.

44. G. L. Gresham, G. S. Groenewold, and J. E. Olson, J. Mass Spectrom., 2000, 35, 1460.

45. B. Singh, M. J. Wilson, W. J. McHardy, A. R. Fraser, and G. Merrington, Clay Miner., 1999, 34, 301.

46. C. W. Childs, Z. Pflanzenernahr. Bodenk., 1992, 155, 441.

47. M. Soma, H. Seyama, N. Yoshinaga, B. K. G. Theng, and C. W. Childs, Clay Sci., 1996, 9, 385.

48. H. Seyama, M. Soma, and A. Tanaka, Chem. Geol., 1996, 129, 209.

49. A. E. Blum and L. L. Stillings, in "Chemical Weathering Rates of Silicate Minerals (Reviews in Mineralogy Vol. 31)", ed. A. F. White and S. L. Brantley, 1995, Mineralogical Society of America, Washington, D.C., 291.

50. S. L. Brantley and Y. Chen, in "Chemical Weathering Rates of Silicate Minerals (Reviews in Mineralogy Vol. 31)", ed. A. F. White and S. L. Brantley, 1995, Mineralogical Society of America, Washington, D.C., 119.

51. H. Seyama, A. Tanaka, J. Sato, M. Tsurumi, and M. Soma, in "Water-Rock Interaction (Proceedings of the 9th International Symposium on Water-Rock Interaction)", ed. G. B. Arehart and J. R. Hulston, 1998, Balkema, Rotterdam, 353.

52. R. A. Berner and J. Schott, Am. J. Sci., 1982, 282, 1214.

53. A. Adriaens, D. Goossens, A. Pijpers, G. Van Tendeloo, and R. Gijbels, Surf. Interface Anal., 1999, $27,8$.
54. R. Petrović, R. A. Berner, and M. B. Goldhaber, Geochim. Cosmochim. Acta, 1976, 40, 537.

55. I. J. Muir, G. M. Bancroft, W. Shotyk, and H. W. Nesbitt, Geochim. Cosmochim. Acta, 1990, 54, 2247.

56. W. P. Inskeep, E. A. Nater, P. R. Bloom, D. S. Vandervoort, and M. S. Erich, Geochim. Cosmochim. Acta, 1991, 55, 787.

57. I. J. Muir and H. W. Nesbitt, Geochim. Cosmochim. Acta, 1991, 55, 3181

58. H. W. Nesbitt, N. D. MacRae, and W. Shotyk, J. Geol., 1991, 99, 429.

59. I. J. Muir and H. W. Nesbitt, Geochim. Cosmochim. Acta, 1992, 56, 3979.

60. W. Shotyk and H. W. Nesbitt, Geoderma, 1992, 55, 55.

61. P. Schweda, L. Sjöberg, and U. Södervall, Geochim. Cosmochim. Acta, 1997, 61, 1985.

62. I. J. Muir and H. W. Nesbitt, Geochim. Cosmochim. Acta, 1997, 61, 265.

63. H. W. Nesbitt and W. M. Skinner, Geochim. Cosmochim. Acta, 2001, 65, 715 .

64. H. Seyama, K. Kinoshita, and M. Soma, Surf. Interface Anal., 2002, 34, 289.

65. J. P. Hamilton, S. L. Brantley, C. G. Pantano, L. J. Criscenti, and J. D. Kubicki, Geochim. Cosmochim. Acta, 2001, 65, 3683.

66. H. H. Teng, P. Fenter, L. Cheng, and N. C. Sturchio, Geochim. Cosmochim. Acta, 2001, 65, 3459.

67. Y. Chen, S. L. Brantley, and E. S. Ilton, Chem. Geol., 2000 163,115

68. J. Schott and R. A. Berner, in "The Chemistry of Weathering", ed. J. I. Drever, 1985, Reidel, Dordrecht, 35.

69. K. Fujimoto and F. Sakamoto, in "Water-Rock Interaction (Proceedings of the 8th International Symposium on Water-Rock Interaction)", ed. Y. K. Kharaka and O. V. Chudaev, 1995, Balkema, Rotterdam, 145.

70. O. S. Pokrovsky and J. Schott, Geochim. Cosmochim. Acta, 2000, 64, 3299.

71. J. Schott and J.-C. Petit, in "Aquatic Surface Chemistry", ed. W. Stumm, 1987, John Wiley \& Sons, New York, 293.

72. J. Schott, R. A. Berner, and E. L. Sjöberg, Geochim. Cosmochim. Acta, 1981, 45, 2123.

73. B. E. Kalinowski, L. J. Liermann, S. L. Brantley, A. Barnes, and C. G. Pantano, Geochim. Cosmochim. Acta, 2000, 64, 1331

74. M. Kobayashi, A. Sawada, Y. Tani, M. Soma, A. Tanaka, T. Honma, H. Seyama, and B. K. G. Theng, Water, Air, Soil Pollut., 2001, 130, 757.

75. H. W. Nesbitt and I. J. Muir, Nature, 1988, 334, 336.

76. H. Seyama, M. Soma, and M. Nanzyo, in "Secondary Ion Mass Spectrometry SIMS XII", ed. A. Benninghoven, P. Bertrand, H.-N. Migeon, and H. W. Werner, 2000, Elsevier Science, Amsterdam, 973

77. M. Kawano and K. Tomita, Clays Clay Miner., 1996, 44, 672.

78. D. W. Mogk and W. W. Locke, III, Geochim. Cosmochim. Acta, 1988, 52, 2537.

79. E. Balan, P. Trocellier, J. Jupille, E. Fritsch, J.-P. Muller, and G. Calas, Chem. Geol., 2001, 181, 13.

80. M. A. Nugent, S. L. Brantley, C. G. Pantano, and P. A. Maurice, Nature, 1998, 395, 588.

81. A. F. White, in "Chemical Weathering Rates of Silicate Minerals (Reviews in Mineralogy Vol. 31)", ed. A. F. White and S. L. Brantley, 1995, Mineralogical Society of America, Washington, D.C., 407. 